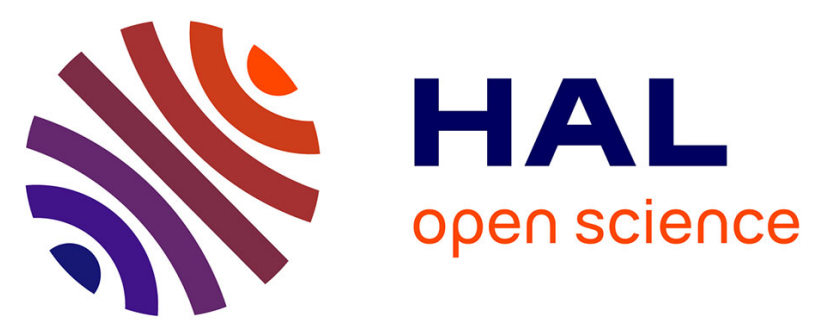

\title{
Tracing of dissolved organic matter from the SEPETIBA bay (Brazil) by PARAFAC analysis of total luminescence matrices
}

Xavier Luciani, Stéphane Mounier, H.H.M Paraquetti, Roland Redon, Yves Lucas, André Bois, L.D. Lacerda, M. Raynaud, M. Ripert

\section{To cite this version:}

Xavier Luciani, Stéphane Mounier, H.H.M Paraquetti, Roland Redon, Yves Lucas, et al.. Tracing of dissolved organic matter from the SEPETIBA bay (Brazil) by PARAFAC analysis of total luminescence matrices. Marine Environmental Research, 2008, 65 (2), pp.148. 10.1016/j.marenvres.2007.09.004 . hal-00501925

\section{HAL Id: hal-00501925 https://hal.science/hal-00501925}

Submitted on 13 Jul 2010

HAL is a multi-disciplinary open access archive for the deposit and dissemination of scientific research documents, whether they are published or not. The documents may come from teaching and research institutions in France or abroad, or from public or private research centers.
L'archive ouverte pluridisciplinaire HAL, est destinée au dépôt et à la diffusion de documents scientifiques de niveau recherche, publiés ou non, émanant des établissements d'enseignement et de recherche français ou étrangers, des laboratoires publics ou privés. 


\section{Accepted Manuscript}

Tracing of dissolved organic matter from the SEPETIBA bay (Brazil) by PARAFAC analysis of total luminescence matrices

X. Luciani, S. Mounier, H.H.M Paraquetti, R. Redon, Y. Lucas, A. Bois, L.D. Lacerda, M. Raynaud, M. Ripert

PII: S0141-1136(07)00116-X

DOI: 10.1016/j.marenvres.2007.09.004

Reference: MERE 3145

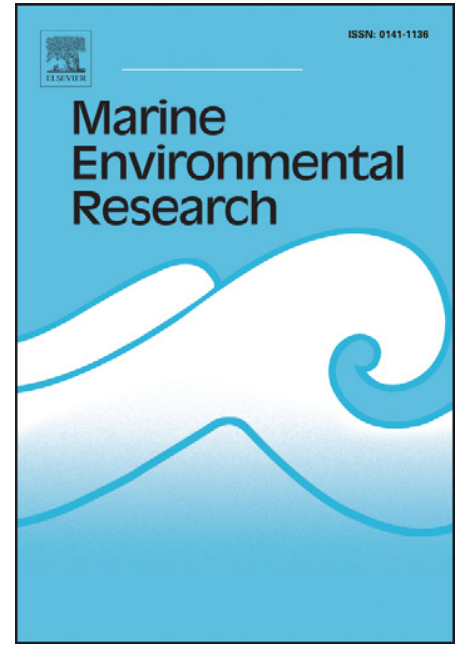

To appear in:

Marine Environmental Research

Received Date:

4 April 2007

Revised Date:

18 September 2007

Accepted Date:

20 September 2007

Please cite this article as: Luciani, X., Mounier, S., Paraquetti, H.H.M, Redon, R., Lucas, Y., Bois, A., Lacerda, L.D., Raynaud, M., Ripert, M., Tracing of dissolved organic matter from the SEPETIBA bay (Brazil) by PARAFAC analysis of total luminescence matrices, Marine Environmental Research (2007), doi: 10.1016/j.marenvres. 2007.09.004

This is a PDF file of an unedited manuscript that has been accepted for publication. As a service to our customers we are providing this early version of the manuscript. The manuscript will undergo copyediting, typesetting, and review of the resulting proof before it is published in its final form. Please note that during the production process errors may be discovered which could affect the content, and all legal disclaimers that apply to the journal pertain. 
Tracing of dissolved organic matter from the SEPETIBA bay (Brazil) by PARAFAC analysis of total luminescence matrices.

X. Luciani ${ }^{1 *}$, S. Mounier ${ }^{2}$, H. H. M Paraquetti ${ }^{3-4}$, R. Redon ${ }^{1}$, Y. Lucas $^{2}$, A. Bois ${ }^{1}$, L.D. Lacerda ${ }^{4}$, M. Raynaud ${ }^{1}$, M. Ripert ${ }^{1}$

1-Laboratoire PROTEE-ISO Université du Sud Toulon Var, BP 20132, 83957 La Garde Cedex 2-Laboratoire PROTEE-CAPTE Université du Sud Toulon Var, BP 20132, 83957 La Garde Cedex 3-Departamento de Geoquímica, Universidade Federal Fluminense, Campus do Valonguinho, Niterói, 2020-007, RJ, Brazil

4-Instituto de Ciências do Mar, Universidade Federal do Ceará, Av. Abolição 3207, Fortaleza, 60165-081, CE, Brazil

Corresponding author : Xavier Luciani, Laboratoire PROTEE-ISO Université du Sud Toulon Var, BP 20132, 83957 La Garde Cedex, France.

Telephone number: 0033494142516

Fax number: 0033494142168

E-mail: lucianix@gmail.com 
Abstract

Fluorescent Excitation-Emission Matrices (FEEM) of the Fluorescent Dissolved Organic Matter

(FDOM) are widely used for DOM characterization and tracing. In this work, a set of FEEM from sampling campaigns in the Sepetiba Bay (Brazil) was decomposed into independent components using the parallel factor analysis (PARAFAC) algorithm. Four independent components were extracted describing the total fluorescence of the FDOM. The well described peaks A, C, M, B and $\mathrm{T}$ were found, and a new peak, $\mathrm{A}^{\prime}$, linked to the $\mathrm{C}$ peak, was detected. Relative contribution of each of four components to the total fluorescence confirms that the coastal water has DOM of terrestrial origin, except for the $275 \mathrm{Ex} / 400-500 \mathrm{Em}$ range $(\mathrm{nm})$, which primarily occurs in marine waters.

Keywords: Coastal waters; Organic matter; Luminescence; Mathematical methods;

PARAFAC; 


\section{Introduction}

Fig.1.

Sepetiba Bay (Fig.1) is a Brazilian semi-enclosed water body located at latitude $23^{\circ} \mathrm{S}$ and longitude $44^{\circ} \mathrm{W}$, about $60 \mathrm{~km}$ south of Rio de Janeiro city whose fast and unplanned development has resulted in high contamination. The site has been studied for many years (Karez et al., 1987; Ovalle et al.,1990; Barcellos and Lacerda, 1994; Marins et al., 1998; Mounier et al., 2001; Lacerda et al., 2001) particularly concerning metal pollution (Paraquetti et al., 2004). A description of the environment is well documented in Lacerda et al. (2001). Some studies were carried out on the role of organic matter (Mounier et al., 2001; Lacerda et al., 2001) but few on its tracing.

Dissolved organic matter (DOM) is present in numerous environmental media. Its role in transport is the focus of many research teams (Marins et al., 1996; Benaim and Mounier, 1998; Mounier et al., 2001). DOM has fluorescent properties which permit monitoring in soils (Miano and Senesi, 1992; Trubetskaya et al., 2002), rivers (Ahmad et al., 2002), estuaries (Stedmon et al., 2003a; Jaffé et al., 2004), waste waters (Galapate et al., 1998; Vasel and Praet, 2002) or sea waters (Baker and Spencer, 2004; Kowalczuk et al., 2005).

The first studies used fluorescence emission spectra in order to determine the origin of the fluorescent DOM (FDOM), but they were only discriminating in terms of the fluorescence efficiency and emission peak's position (Senesi et al., 1991). Ten years ago, technological advances meant that, it was possible to rapidly obtain synchronous spectra (Cabaniss and Shuman, 1987) and Fluorescence Excitation-Emission Matrices (FEEM) (Coble, 1996). Since the reference work of Coble (1996), the FDOM is described by fluorescence maximum localization, giving qualitative information for determining the origin of DOM. Some ubiquitous peaks were rapidly detected, such as peaks A, C, D and M referenced by their emission-excitation range (Mobed et al., 1996; Parlanti et al., 2000; Patel-Sorrentino et al., 2002; Kowalczuk et al., 2005). But, as the total luminescence is a mix of a large number of different fluorescent compounds, the interpretation of variations and comparisons between studies are at present difficult. For these reasons, mathematical tools such as Principal Component Analysis (PCA) are commonly used to obtain this information (Persson and Wedborg, 2001; Boehme et al., 2004, Esteves da Silva et al., 2006).

Recently, the PARAFAC (Parallel Factors Analysis) algorithm was successfully used to treat a large amount of FDOM samples analyzed by FEEM, leading to the decomposition of a set of fluorescent compounds (Stedmon et al., 2003a; Stedmon and Markager, 2003b; Stedmon and Markager, 2005; Holbrook et al., 2006). Due to its unique properties, PARAFAC modeling 


\section{ACCEPTED MANUSCRIPT}

provides a singular spectral decomposition which is more readily interpretable than bilinear decompositions. This work has two main goals: (1) the characterization of the fluorescent dissolved organic matter (FDOM) in the bay by extraction of the fluorescing spectra, and (2) the emphasis of the river effects on the FDOM tracing through the bay. The spectral representation of the components obtained from PARAFAC analysis of a set of coastal catchments is compared with the Coble peaks. Then, the sample scores in this PARAFAC analysis are used for FDOM tracing.

\section{Materials and Methods}

\subsection{Data collection and pretreatment.}

\section{Fig.2.}

Several results are available in the literature dealing with the geochemical role of organic matter in the Sepetiba bay (Mounier et al., 2001; Paraquetti et al., 2004). Samples from coastal waters were taken during several campaigns carried out in Sepetiba Bay: in 2000 the northern coastal and outer bay samples, influenced by mining processes (Mad campaign); in 2001 the southern bay samples (Tran campaign); and the last in 2005 for input river samples (Rivers campaign) including a mangrove sample taken during low tide. Samples characteristics and references are shown in Table 1 and the sampling location is given in Fig.2.

All samples were measured by 3D-fluorescence spectroscopy after filtration on site through a GFfilter (pre-heated to $450^{\circ} \mathrm{C}$ ) to separate the particulate organic matter and the dissolved organic matter. GF-filters were chosen to avoid carbon contamination on further analysis. Before being analyzed, samples were fixed by an addition of $100 \mu \mathrm{L}$ of $1 \mathrm{M} \mathrm{NaN} \mathrm{N}_{3}$ (Aldrich) solution for each 250 $\mathrm{mL}$ of sample and conserved at $4{ }^{\circ} \mathrm{C}$ in the dark. Sampling flasks were cleaned by nitric acid $10 \%$, rinse several time by milliQ water and stored dry before use. All analysis were completed within two months of sampling. Salinity and $\mathrm{pH}$ were measured on site whenever possible. The Dissolved Organic Carbon (DOC) measurements were done with a high temperature combustion Shimadzu TOC-5000, using a four point potassium hydrogen phthalate calibration curve.

Table 1

Before analysis for DOC, samples ( $5 \mathrm{~mL}$ ) were acidified by $100 \mu \mathrm{L}$ hydrochloric acid $30 \%$ (Aldrich) and bubbled by a $\mathrm{CO}_{2}$-free nitrogen flux for ten minutes to eliminate the inorganic carbon. 


\section{ACCEPTED MANUSCRIPTI}

Triplicates were analysed until the relative standard deviation reached 2\%. The FEEM were obtained from Hitachi F4500 with the following settings: speed scan $30000 \mathrm{~nm} / \mathrm{min}$, excitation and emission bandwidth $5 \mathrm{~nm}$, excitation and emission step $3 \mathrm{~nm}$, response $0.04 \mathrm{~s}$, excitation interval $200 \mathrm{~nm}$ to $500 \mathrm{~nm}$, emission interval $250 \mathrm{~nm}$ to $600 \mathrm{~nm}$. Response was automatically corrected for the excitation light fluctuation. Samples were bubbled with nitrogen for ten minutes to remove dissolved oxygen. The resulting 35 FEEM were numerically corrected to eliminate the Rayleigh and Raman scattering peaks using the three-dimensional interpolation of the data (Delaunay triangulation method) proposed in Zepp et al. (2004). All the 35 corrected FEEM were gathered in a 3-way data array. Before processing it is necessary to remove from the data array, samples with high leverage and residual. For this purpose, the data array was first unfolded into a $(35 \times 4331)$ matrix by combining the two spectral modes. Then, a PCA was performed on the variable space in order to highlight the correlations between samples and to detect possible outliers. No outlier was identified with this primary procedure. A post-analysis will refine this result.

\subsection{Parallel Factor Analysis (PARAFAC) of FEEM data.}

Since the theory was at first developed for psychology applications by Harshman (1970),

PARAFAC is now widely used in various scientific works as a powerful decomposition algorithm. In this paragraph, the method is briefly described, but we refer to the existing literature for further descriptions of the PARAFAC theory and algorithms (Harshman, 1970; Harshman and Lundy, 1994; Bro, 1997; Faber et al, 2003). An interesting review about PARAFAC analysis of FEEM data can be found in Andersen and Bro (2003).

PARAFAC is a multi-way analysis method based on a multilinear decomposition of the data set. In fluorescence spectroscopy, one analyzes a set sample in which each FEEM is a different mixture of $F$ underlying fluorescent components. Considering $x_{i, j, k}$ as the fluorescence intensity of a given sample $i$ at a given couple $(j, k)$ of excitation and emission wavelengths, $a_{i f}$ as the concentration of the component $f$ in the sample $i, b_{i f}$ as the amount of fluorescence intensity emitted by $f$ at the emission wavelength $\lambda_{j}$ and $c_{k f}$ as the amount of excitation intensity absorbed by $f$ at the excitation wavelength $\lambda_{k}$, the Beer-Lambert law gives in a first order approximation:

$$
\forall(i, j, k) \in([1 ; I],[1 ; J],[1 ; K]), x_{i, j, k}=\sum_{f=1}^{F} a_{i f} b_{j f} c_{k f}+\mathcal{E}_{i, j, k}
$$

Where $\varepsilon$ is the residual error term. This trilinear relationship between a measured variable $x_{i, j, k}$ and three other unknown variables is a 3-way PARAFAC model of rank $F$.

For each component, $f$, vectors $\mathbf{a}_{f}, \mathbf{b}_{f}$ and $\mathbf{c}_{f}$ represent respectively its concentration profile through the samples set, its normalized emission spectrum and its normalized excitation spectrum. These vectors are called the loading vectors of the decomposition. As many other linear decomposition 
methods like PCA, PARAFAC minimizes the error term to find the optimal loading vectors in a least square sense. In order to ensure the convergence of the PARAFAC model, we used in this work the Alternating Least Square algorithm (ALS) (Bro, 1997; Faber et al., 2003) of the 'N-way toolbox for MATLAB' (Anderson and Bro, 2002), with non negativity constraints on the three modes. This algorithm provide a good and fast estimation of the loading vectors. The $F$ matrix products, $\mathbf{b}_{f} \mathbf{c}_{f f}^{\mathbf{t}}$, provide a normalized FEEM "basis" of the set sample while vectors $\mathbf{a}_{f}$ are stored in the $F$ columns of the score matrix $\mathbf{A}$. Therefore, the $i^{\text {th }}$ row of $\mathbf{A}$ contains the scores of the $i^{\text {th }}$ sample in the PARAFAC components basis. Thanks to the linear independence between the loadings and the trilinear nature of the data set, the solution of the PARAFAC decomposition is unique, in the exception of the trivial indetermination on loadings scale and order (Harshman, 1972; Sidiropoulos and Bro, 2000). This provides a very well defined outcome compared to bilinear methods which makes the PARAFAC analysis an appropriate technique for chemical interpretations.

However, the number of significant fluorescing species in the samples is unknown. Without a priori knowledge (de la Peña et al., 2006), several methods help to determine the "best number of components" or best model rank, which is a crucial step of the PARAFAC processing. Residual variance analysis, Core Consistency Diagnostic (CORCONDIA) (Bro and Kiers, 2003) and split half analysis (Harshman et al., 1994) were used in this study. The first runs of the algorithm were made without any other pre-treatment. During this preliminary step, it was pointed out than nine samples (15-17, 25-29 and 35) exhibited a high leverage level. This small number of highly fluorescing samples could have a disproportionate influence on the ALS convergence. Therefore these could hide some components which could be present in the set sample but not in this influencing subset. However, the relative residual variance was less than 5\% for every sample arguing there was no outlier. This assumption was confirmed by the Identity Match Plots from a jackknife procedure (Riu and Bro, 2002) (not shown). Consequently, all the samples were kept in the data set but, each 35 FEEM were weighed by the inverse Euclidian norm before new processing. With this weighed data set, the CORCONDIA was $92 \%, 66.73 \%, 40.15 \%, 33.33 \% 17.68 \%$ for the two to six components models. However the variance explained percentages were respectively $94.17 \%, 96.21 \%, 98.23 \%, 98.55 \%$ and $98.84 \%$, indicating that the third and fourth components have a reasonable usefulness while the fifth and the sixth components should describe the noise or non-trilinear deviations. Moreover, the spectral shape of the components obtained with the four component model was meaningful. In addition, a "split half analysis" was tried by splitting the sample mode in two partitions of independent halves. The best correlations (above 0.9) between the loadings of the two spectral modes for each spectrum were found for the four component model. According to these results the linear least square estimation of the sample scores was performed by 


\section{ACCEPTED MANUSCRIPT}

fitting a four component PARAFAC model on the raw data set, with the spectral loadings obtained

from the weighted data set. Finally this model gave a good general description of all the samples in the data set and the dissimilarities were mostly localized in zones with almost no fluorescing signal. One should note that fluorescence excitation measures under $250 \mathrm{~nm}$ are usually avoided with standard spectrofluorimeter. This is due to the lamp limitations which degrade the signal to noise ratio at the lowest wavelengths. In order to evaluate the influence of the noisy $200-250 \mathrm{~nm}$ excitation range, all the FEEM were cut down under $250 \mathrm{~nm}$ in excitation. Then the PARAFAC results between the original and truncated data sets were compared in the excitation range above $250 \mathrm{~nm}$. The model rank was estimated to four in both cases and no significant modification of the loadings shape was found whether the $200-250 \mathrm{~nm}$ range was included or not. Actually, the noise in this region is modeled when more than four components are used. In addition, a large part of one excitation peak would be lost if the data were truncated. Eventually, the 200-250 nm excitation range was kept in the PARAFAC proceeding.

\section{Results and discussion}

\subsection{PARAFAC spectral results}

The spectral loadings and the corresponding four components based on FEEM are presented in Fig.3. These components are similar to the Stedmon results (Stedmon et al., 2003a; Stedmon et al., 2006). They are compared to the Coble (1996) and Parlanti (2000) peaks in Table 2. Component 1 is composed of two non-separated peaks of different excitation. One with a wavelength domain about 350/400-450 which corresponds to the type $\mathrm{C}$, humic like compound, and one ranging in the domain 275/400-500 (noted A'). This last peak is excited at a similar wavelength as the tyrosine type but with a red-shifted emission range of about $100 \mathrm{~nm}$. Component 2 (255/380-460) is typical of the A type, described by Coble (1996). Component 3 (320/380-420) matches the M type, initially described as marine humic-like matter. Finally, the component 4 is similar to the protein like compounds. It includes the B and T types as the emission domain is large (275/300-360). Note that the component $\mathrm{A}^{\prime}$ is red shifted compared to the excitation wavelength of component 2 (type A).

Table 2

Fig.3.

\subsection{FDOM tracing.}




\section{ACCEPTED MANUSCRIPT}

Five geographical sample classes were chosen a priori, having undergone anthropic influence.

These regroup, in ascending order of anthropic-influence, from the bay samples (class 1), presumably less influenced by the river inputs, the western (class 2a) and eastern (class 2b) coastal samples, the western river samples (class 3a) and the eastern river samples (class 3b). Although the condensed representation of the sample set in the four-dimensional PARAFAC analysis is much more informative than the original FEEM set, some basic statistical treatments of the sample scores are performed in order to achieve the sample classification.

Fig.4. represents the mean proportions of the four components in each of the five classes. Two main kinds of samples are clearly discriminated. The three marine classes (1, 2a and $2 \mathrm{~b})$ show very similar and quite balanced profiles with a dominant contribution of component 2 and 3 . On the other hand, component 2 almost disappears in the river classes (3a-b) contributions, where component 1 is highly dominant. The component 1 represents a terrigenic character as its contribution is twice as important in river compared to the marine samples (Fig.4.). This component is composed of two peaks, C and A' (Fig.5.). The type A' fluorophore was poorly described before, but the type $C$ is usually described as a specific terrigenic signal (Coble, 1996; Parlanti, 2000).

Component 2 is characteristically marine. On another hand, component 3 was initially described as marine in origin by Coble (1996) and Parlanti (2000), but this is not the case here. This component is slightly more important in marine than in the river samples, but is not characteristically marine. The contradiction was already pointed out by Stedmon et al. (2003a) when they observed this component in "terrestrially dominated end-member samples". The terrigenic contribution is less and less important in the marine samples fluorescence but never vanishes, and stays almost as important as the component 2 signal. This means that a major part of the marine FDOM is from terrestrial origin. In this study, only the component 2 seems to be marine in origin. Moreover in marine FDOM, the protein-like signal is less important than in river FDOM, and its contribution to the fluorescence signal increase from coast to bay exit.

From a statistical point of view, the PARAFAC analysis should provide some redundant information and a more condensed representation may be beneficial for the classification. Consequently, a PCA of the PARAFAC score matrix is performed as proposed in Ohno and Bro (2006). The principal components are linear combinations of the PARAFAC components and have no physical meaning but the subspace spanned by only the first two principal components explains more than $98 \%$ of the samples variance. Therefore, the sample representation in this plan (Fig.5.) should reveal some new information and makes the classification simpler. The PCA confirms the discrimination between river and marine samples as these two kinds of samples are clearly distributed around two different axis. Furthermore, it highlights the degree of difference between samples. In the eastern part of the bay, Piraque, Ita, Guandu, Sao Francisco and Guarda rivers have 


\section{ACCEPTED MANUSCRIPT}

a strong fluorescence signal compared to the Itimirim and Itinguçu rivers. This is due to the morphologic difference between these two types of catchment area. The urbanization is far more dense in the east. In comparison, Itimirim and Itinguçu are smaller and non urbanized rivers. The marine samples are also discriminated by their signal amplitude. There is a general tendency for the fluorescence signal of the marine samples to gradually decrease from terrestrial to open sea samples. This is confirmed for each of the four components and supports the observations in previous studies (Stedmon et al., 2003a; Stedmon et al., 2003b) as a result of FDOM sinking in estuary zone.

Fig.4.

Fig.5.

\section{Conclusion}

The data treatment of a subtropical FEEM series by PARAFAC analysis describes four fluorescent components within the fluorescent dissolved organic matter. One spectral contribution (255/380460) to the fluorescent organic matter and its evolution in this environment gives a clear distinction between river and marine waters. All the previous fluorescent peaks A,M,C,T and B were found in this study. A new terrestrial fluorescent moiety, the A' (275/400-500) peak, linked to the C type component was present in these subtropical samples. Hence, each component can be described as a contribution to the total luminescence signal. Surprisingly in this study, the component number 3 whose domain corresponds to the $\mathrm{M}$ type, is not characteristic of marine waters. Only the A type (humic-like compound) is really a feature of marine samples. This study, using PARAFAC analysis on FEEM samples shows that the fluorescence response the marine FDOM is principally due to terrestrial FDOM except for the 255/380-460 domain. The terrestrial FDOM is diluted in the bay and is in similar proportion to the marine FDOM even for the more seaward-samples. More investigations are required to understand why only the A type component is characteristic of marine waters in these sub-tropical samples. PARAFAC provides a useful tool to discriminate between different components contributing to the FDOM in the coastal environment.

\section{Acknowledgments}




\section{ACCEPTED MANUSCRIPT}

Thanks to Dr. D. Février and Pr. J. Maddock from the federal university of Niteroi for the sampling campaign and on site help. Part of this work was supported by the CAPES-COFECUB fund.

\section{References}

Ahmad, U.K., Ujang, Z., Yusop, Z., and Fong, T.L., (2002). Fluorescence technique for the characterization of natural organic matter in river water. Water Science and Technology, 46(9), 117-125.

Andersson, C.A. and Bro, R., (2002). The N-way toolbox for Matlab. Chemometrics and Intelligent Laboratory Systems, 52, 1-4 (toolbox available at http://www.models.kvl.dk/source/ ).

Baker, A., and Spencer, R.G.M., (2004). Characterisation of dissolved organic matter from source to sea using fluorescence and absorbance spectroscopy. The Science of the Total Environment, $333(1-3), 217-232$.

Barcellos, C. and Lacerda, L.D., (1994). Cadmium and zinc source assessment in the Sepetiba Bay and basin region. Environmental Monitoring and Assessment, 29(2), 183-199.

Benaim, J.Y. and Mounier, S., (1998). Metal transport by organic carbon in the Amazon Basin. Croatica Chemica Acta ,71(2), 405-419.

Boehme, J., Coble, P., Conmy, R. and Stovall-Leonard, A., (2004). Examining CDOM fluorescence variability using principal component analysis: seasonal and regional modeling of threedimensional fluorescence in the Gulf of Mexico. Marine Chemistry, 89, 3-14.

Bro, R., (1997). PARAFAC. Tutorial and applications. Chemometrics and Intelligent Laboratory Systems, 38, 149-171.

Bro, R. and Kiers, H.A.L. (2003). A new efficient method for determining the number of components in PARAFAC models. Journal of Chemometrics, 17, 274-286.

Cabaniss, S.E. and. Shuman, M.S., (1987). Synchronous fluorescence spectra of natural waters: sources of dissolved organic matter. Marine Chemistry, 21(1), 37-50.

Coble, G.P., (1996). Characterization of marine and terrestrial DOM in seawater using excitationemission matrix spectroscopy. Marine Chemistry, 51, 325-346.

de la Peña, A.M., Díez, N.M., Gil, D.B., Olivieri, A.C. and Escandar, G.M., (2006). Simultaneous determination of flufenamic and meclofenamic acids in human urine samples by second-order multivariate parallel factor analysis (PARAFAC) calibration of micellar-enhanced excitationemission fluorescence data. Analytica Chimica Acta, 569(1-2), 250-259

Esteves da Silva, J.C.G., Tavares, M.J.C.G., and Tauler, R., (2006). Multivariate curve resolution of multidimensional excitation-emission quenching matrices of a Laurencian soil fulvic, acid.

Chemosphere, 64, 1939-1948. 
Faber, N.M., Bro R. and Hopke, P.K., (2003). Recent developments in CANDECOMP/PARAFAC algorithms: a critical review. Chemometrics and Intelligent Laboratory Systems, 65, 119-137.

Galapate, R.P., Baes, A.U., Ito, K., Mukai, T., Shoto, E. and Okada, M., (1998). Detection of domestic waste in kurose river using synchronous fluorescence spectroscopy. Water Research, 32(7), 2232-2239.

Harshman, R.A., (1970). Foundations of the PARAFAC procedure: Models and conditions for an "explanatory" multi-modal factor analysis. UCLA Working Papers in Phonetics, 16, 1-84. (UMI Serials in Microform, No. 10,085).

Harshman, R.A., (1972). Determination and proof of minimum uniqueness conditions for PARAFAC1. UCLA Working Papers in Phonetics, 22, 111-117. (UMI Serials in Microform, No. 10,085).

Harshman, R.A. and Lundy, M.E., (1994). PARAFAC: Parallel factor analysis. Computational Statistics and Data Analysis, 18, 39-72.

Holbrook, R.D., Yen, J.H. and Grizzard, T.J., (2006). Characterizing natural organic material from the Occoquan Watershed (Northern Virginia, US) using fluorescence spectroscopy and PARAFAC. Science of The Total Environment, 361(1-3), 249-266.

Jaffé, R., Boyer, J.N., Lu, X., Maie, N., Yang, C., Scully, N.M. and Mock, S., (2004). Source characterization of dissolved organic matter in a subtropical mangrove-dominated estuary by fluorescence analysis. Marine Chemistry, 84, 195-210.

Karez, C.S., Magalhaes, V.F., Pfeiffer, W.C. and Amado, G.M., (1987). Trace metal accumulation by algae in Sepetiba Bay, Brazil. Environmental Pollution, 83(3), 351-356.

Kowalczuk, P., Stoń-Egiert, J., Cooper, W.J., Whitehead, R.F. and Durako, M.J., (2005). Characterization of chromophoric dissolved organic matter (CDOM) in the Baltic Sea by excitation emission matrix fluorescence spectroscopy. Marine Chemistry, 96(3-4), 273-292.

Lacerda, L.D., Marins, R.V., Paraquetti, H.H.M., Mounier, S., Benaim, J., and Février, D., (2001). Mercury distribution and reactivity in waters of a subtropical coastal lagoon, Sepetiba Bay, SE Brasil. Journal of the Brazilian Chemical Society, 12(1), 93-98.

Marins, R.V, Silva Filho, E.V., and Lacerda, L.D., (1996). Atmospheric Deposition of Mercury over Sepetiba Bay. SE Brazil, Sociedade Brasileira de Quimica, 7(3), 177-180.

Marins, R.V., Lacerda, L.D., Paraquetti, H.H.M., de Paiva, E.C., and Villas, R.C., (1998). Geochemistry of mercury in sediments of a sub-tropical Coastal Lagoon, Sepetiba Bay, Southeastern Brazil. Bulletin of Environmental Contamination and Toxicology, 61(1), 57-64.

Miano, T.M. and Senesi, N., (1992). Synchronous excitation fluorescence spectroscopy applied to soil humic substances chemistry. The Science of the Total Environment, 117, 41-51.

Mobed, J.J., Hemmingsen, S.L., Autry, J.L. and McGown, L.B., (1996). Fluorescence characterization of IHSS humic substances: total luminescence spectra with absorbance correction. Environmental Science \& Technology, 30(10), 3061-3065. 


\section{ACCEPTED MANUSCRIPT}

Mounier, S., Lacerda, L.D., Marins, R.V. and Benaim, J., (2001). Copper and Mercury Complexing Capacity of Organic Matter From a Mangrove Mud Flat Environment, Sepetiba Bay, Brazil. Environmental Contamination and Toxicology, 67, 519-525.

Ohno, T. and Bro, R., (2006). Dissolved Organic Matter Characterization Using Multiway Spectral Decomposition of Fluorescence Landscapes. Soil Science Society of America Journal, 70, 20282037.

Ovalle, A.R.C., Rezende, C.E., Lacerda, L.D. and Silva, C.A.R., (1990). Factors affecting the hydrochemistry of a mangrove tidal creek, Sepetiba Bay, brazil. Estuarine, Coastal and Shelf Science, 31(5), 639-650.

Paraquetti, H.H.M., Ayres, G.A., de Almeida, M.D., Molisani, M.M. and Lacerda, L.D., (2004). Mercury distribution, speciation and flux in the Sepetiba Bay tributaries. SE Brazil, Water Research, 38(6), 1439-1448.

Parlanti, E., Wörz, K., Geoffroy, L. and M. Lamotte, M., (2000). Dissolved organic matter fluorescence spectroscopy as a tool to estimate biological activity in a coastal zone submitted to anthropogenic inputs. Organic Geochemistry, 31(12), 1765-1781.

Patel-Sorrentino, N., Mounier, S. and Benaim, J., (2002). Excitation-emission fluorescence matrix to study $\mathrm{pH}$ influence on organic matter fluorescence in the Amazon basin. Water Research, 36(10), 2571-2581.

Persson, T. and Wedborg, M., (2001). Multivariate evaluation of the fluorescence of aquatic organic matter. Analytica Chimica Acta, 434, 179-192.

Riu, J. and Bro, R., (2002). Jack-knife technique for outlier detection and estimation of standard errors in PRAFAC models. Chemometrics and Intelligent Laboratory Systems, 65, 35-49.

Senesi, N., Miano, T.M., Provenzano, M.R., and Brunetti, G., (1991). Characterization, differentiation, and classification of humic substances by fluorescence spectroscopy. Soil Science, $152(4), 259-271$.

Sidiropoulos, N.D. and Bro, R. (2000). On the uniqueness of multilinear decomposition of N-way arrays. Journal of Chemometrics, 14(3), 229-239.

Stedmon, C.A., Markager, S. and Bro, R., (2003a). Tracing dissolved organic matter in aquatic environments using a new approach to fluorescence spectroscopy. Marine Chemistry, 82(3-4), 239254.

Stedmon, C.A. and Markager, S., (2003b). Behaviour of the optical properties of coloured dissolved organic matter under conservative mixing. Estuarine, Coastal and Shelf Science, 57, 1-7.

Stedmon, C.A. and Markager, S., (2005). Resolving the variabillity in dissolved organic matter fluorescence in a temperate estuary and its catchment using PARAFAC analysis. Limnology and Oceanography, 50(2), 686-697.

Trubetskaya, O., Trubetskoj, O., Guyot, G., Andreux, F. and Richard, C., (2002). Fluorescence of soil humic acids and their fractions obtained by tandem size exclusion chromatographypolyacrylamide gel electrophoresis. Organic Geochemistry, 33(3), 213-220. 


\section{ACCEPTED MANUSCRIPT}

Vasel, J.L., and Praet, E., (2002). On the use of fluorescence measurements to charaterize wastewater. Water Science and Technology, 45(4-5), 109-116.

Zepp, R.G., Sheldon, W.M. and Moran, M.A., (2004). Dissolved organic fluorophores in southeastern US coastal waters: correction method for eliminating Rayleigh and Raman scattering peaks in excitation-emission matrices. Marine Chemistry, 89, 15- 36. 
Figure captions :

Fig.1. Location of the Sepetiba Bay, Brazil.

Fig.2. Sampling map of the campaigns: Mad ( $\boldsymbol{\Delta}$ symbols), Trans ( $\boldsymbol{a})$ and Rivers (o) localization.

Fig.3. Spectral representations of the normalized PARAFAC components (1 to 4): FEEM representation (left) and the corresponding individual excitation (solid lines) and emission (dotted lines) spectra (right).

Fig.4. Relative mean contributions of each PARAFAC component ( 1 to 4 , from lighter to darker grey) in the five geographical sample classes from open bay (1) to riverine (3a, 3b). Error bars represent the standard deviations.

Fig.5. Sample scores for the first two principal components (respectively $85 \%$ and $14 \%$ of variance explained) of the PARAFAC score matrix. $\Delta$ symbols are used for class $1, \square$ for class $2 \mathrm{a}_{\text {, }}$ for class $2 \mathrm{~b}, \circ$ for class $3 \mathrm{a}$ and $\square$ for class $3 \mathrm{~b}$. 


\section{ACCEPTED MANUSCRIPT}

Table 1

Sampling campaigns, position, DOC concentration, on site conductivity and $\mathrm{pH}$ measurement.

\begin{tabular}{|c|c|c|c|c|c|c|c|}
\hline \multirow{2}{*}{$\begin{array}{l}\text { Sample } \\
\text { reference }\end{array}$} & \multirow[t]{2}{*}{ Campaign } & \multirow[t]{2}{*}{ Date } & \multicolumn{2}{|l|}{ Position } & \multirow{2}{*}{$\begin{array}{l}\text { DOC } \\
\mathrm{mg} \cdot \mathrm{L}^{-1}\end{array}$} & \multirow{2}{*}{$\begin{array}{l}\text { Cond } \\
\mu \mathrm{S} . \mathrm{cm}^{-1}\end{array}$} & \multirow[t]{2}{*}{$\mathrm{pH}$} \\
\hline & & & $\mathrm{N}$ & $\mathrm{W}$ & & & \\
\hline 1 & Tran & 27 Apr. 2001 & $22^{\circ} 56,20^{\prime}$ & $43^{\circ} 54,94$ & 2,37 & - & 8,2 \\
\hline 2 & Tran & 27 Apr. 2001 & $22^{\circ} 56,70^{\prime}$ & $43^{\circ} 55,68$ & 2,37 & - & 8,3 \\
\hline 3 & Tran & 27 Apr. 2001 & $22^{\circ} 59,23^{\prime}$ & $43^{\circ} 59,48^{\prime}$ & 2,41 & - & 8,3 \\
\hline 4 & Tran & 27 Apr. 2001 & $23^{\circ} 00,95^{\prime}$ & $44^{\circ} 02,07^{\prime}$ & 2,17 & - & 8,2 \\
\hline 5 & Tran & 27 Apr. 2001 & $23^{\circ} 02,13^{\prime}$ & $44^{\circ} 01,74^{\prime}$ & 2,23 & - & 8,3 \\
\hline 6 & Tran & 27 Apr. 2001 & $23^{\circ} 02,13$ & $44^{\circ} 00,94^{\prime}$ & 3,46 & & 8,2 \\
\hline 7 & Tran & 27 Apr. 2001 & $23^{\circ} 02,95^{\prime}$ & $43^{\circ} 58,05$ & 2,13 & & 8,2 \\
\hline 8 & Tran & 27 Apr. 2001 & $23^{\circ} 01,54^{\prime}$ & $43^{\circ} 57,61^{\prime}$ & 2,19 & - & 8,2 \\
\hline 9 & Tran & 27 Apr. 2001 & $23^{\circ} 00,37^{\prime}$ & $43^{\circ} 56,49^{\prime}$ & 3,91 & - & 8,3 \\
\hline 10 & Tran & 27 Apr. 2001 & $22^{\circ} 59,16^{\prime}$ & $43^{\circ} 55,67^{\prime}$ & 2,48 & - & 8,2 \\
\hline 11 & Mad & 21 Nov. 2000 & $22^{\circ} 55,81^{\prime}$ & $43^{\circ} 47,16^{\prime}$ & 2,36 & - & - \\
\hline 12 & Mad & 21 Nov. 2000 & $22^{\circ} 57,66^{\prime}$ & $43^{\circ} 46,12^{\prime}$ & 1,22 & - & - \\
\hline 13 & Mad & 27 Nov. 2000 & $22^{\circ} 55,93^{\prime}$ & $43^{\circ} 52,33^{\prime}$ & 1,49 & - & 8,5 \\
\hline 14 & Mad & 27 Nov. 2000 & $22^{\circ} 55,52^{\prime}$ & $43^{\circ} 49,61^{\prime}$ & 1,57 & - & 8,5 \\
\hline 15 & Mad & 21 Nov. 2000 & $22^{\circ} 55,00^{\prime}$ & $43^{\circ} 45,78^{\prime}$ & 2,23 & - & - \\
\hline 16 & Mad & 21 Nov. 2000 & $22^{\circ} 55,00^{\prime}$ & $43^{\circ} 45,78^{\prime}$ & 2,23 & - & - \\
\hline 17 & Mad & 27 Nov. 2000 & $22^{\circ} 54,97^{\prime}$ & $43^{\circ} 45,71$ & 4,40 & - & 6,8 \\
\hline 18 & Mad & 21 Nov. 2000 & $22^{\circ} 56,85^{\prime}$ & $43^{\circ} 45,78^{\prime}$ & 1,32 & - & - \\
\hline 19 & Mad & 27 Nov. 2000 & $22^{\circ} 55,24^{\prime}$ & $43^{\circ} 52,31^{\prime}$ & 1,87 & - & 8,4 \\
\hline 20 & Mad & 27 Nov. 2000 & $22^{\circ} 55,52^{\prime}$ & $43^{\circ} 49,05^{\prime}$ & 1,50 & - & 8,5 \\
\hline 21 & Mad & 29 Nov. 2000 & $22^{\circ} 55,33^{\prime}$ & $43^{\circ} 53,17^{\prime}$ & 2,13 & - & 8,0 \\
\hline 22 & Mad & 27 Nov. 2000 & $22^{\circ} 54,51^{\prime}$ & $43^{\circ} 52,59^{\prime}$ & 1,34 & - & 8,4 \\
\hline 23 & Mad & 27 Nov. 2000 & $22^{\circ} 59,91^{\prime}$ & $43^{\circ} 49,51^{\prime}$ & 1,99 & - & 8,6 \\
\hline 24 & Mad & 21 Nov. 2000 & $22^{\circ} 56,16^{\prime}$ & $43^{\circ} 46,12$ & 2,48 & - & - \\
\hline 25 & Mad & 27 Nov. 2000 & $22^{\circ} 54,55^{\prime}$ & $43^{\circ} 51,00^{\prime}$ & 1,53 & - & 8,3 \\
\hline 26 & $\mathrm{Mad}$ & 21 Nov. 2000 & $22^{\circ} 57,07^{\prime}$ & $43,44,82^{\prime}$ & 2,67 & - & - \\
\hline 27 & Mad & 27 Nov. 2000 & $22^{\circ} 55,86^{\prime}$ & $43^{\circ} 45,71^{\prime}$ & 4,01 & - & 7,5 \\
\hline 28 & Rios (Ita) & 13 Juin 2005 & $22^{\circ} 53,94^{\prime}$ & $43^{\circ} 41,14^{\prime}$ & 3,44 & 254 & 5,9 \\
\hline 29 & Rios (Guandu) & 13 Juin 2005 & $22^{\circ} 53,84$ & $43^{\circ} 41,59$ & 3,39 & 161 & 6,4 \\
\hline 30 & Rios (Sao Françisco) & 13 Juin 2005 & $22^{\circ} 55,28^{\prime}$ & $43^{\circ} 43,06$ & 4,2 & 62 & 7,2 \\
\hline 31 & Rios (Guarda) & 13 Juin 2005 & $22^{\circ} 52,48^{\prime}$ & $43^{\circ} 44,67$ & 4,18 & 267 & 6,0 \\
\hline 32 & Rios (Itimirim) & 13 Juin 2005 & $22^{\circ} 54,55$ & $43^{\circ} 53,50^{\prime}$ & 9,25 & 98 & 5,8 \\
\hline 33 & Rios (Itinguçu) & 13 Juin 2005 & $22^{\circ} 54,68$ & $43^{\circ} 53,27^{\prime}$ & 7,7 & 45 & 6,8 \\
\hline 34 & Rios (Mangrove) & 13 Juin 2005 & $22^{\circ} 54,95^{\prime}$ & $43^{\circ} 52,72$ & 4,95 & 295 & 6,9 \\
\hline 35 & Rios (Piraque) & 13 Juin 2005 & $22^{\circ} 59,47^{\prime}$ & $43^{\circ} 36,26^{\prime}$ & 6,61 & 294 & 7,1 \\
\hline
\end{tabular}




\section{ACCEPTED MANUSCRIPT}

Table 2

Comparison between the referenced fluorescence peaks and the four PARAFAC components of this study Referenced fluorescence peaks PARAFAC components

\begin{tabular}{|c|c|c|c|c|c|c|c|}
\hline $\begin{array}{c}\text { Parlanti } \\
\text { ref }\end{array}$ & $\begin{array}{c}\text { Coble } \\
\text { ref }\end{array}$ & $\begin{array}{c}\text { Ex max } \\
\text { nm }\end{array}$ & $\begin{array}{c}\text { Em max } \\
\mathrm{nm}\end{array}$ & Coble description & $\begin{array}{c}\text { Component } \\
\text { number }\end{array}$ & $\begin{array}{c}\text { Ex max } \\
n m\end{array}$ & $\begin{array}{c}\text { Em max } \\
\mathrm{nm}\end{array}$ \\
\hline & & & & Humic-like & 1 & 350 & $400-450$ \\
\hline$\alpha$ & $\mathrm{C}$ & 350 & $420-480$ & $\mathrm{~A}^{\prime}$ & 1 & 275 & $400-500$ \\
\hline$\alpha^{\prime}$ & $\mathrm{A}$ & 260 & $380-460$ & Humic-like & 2 & 255 & $380-460$ \\
\hline$\beta$ & M & 312 & $380-420$ & Marine-humic-like & 3 & 320 & $380-420$ \\
\hline$\delta$ & $\mathrm{T}$ & 275 & 310 & $\begin{array}{c}\text { Tryptophan-like, } \\
\text { protein-like } \\
\text { Tyrosine-like, protein- } \\
\text { like }\end{array}$ & 4 & & $300-360$ \\
\hline
\end{tabular}




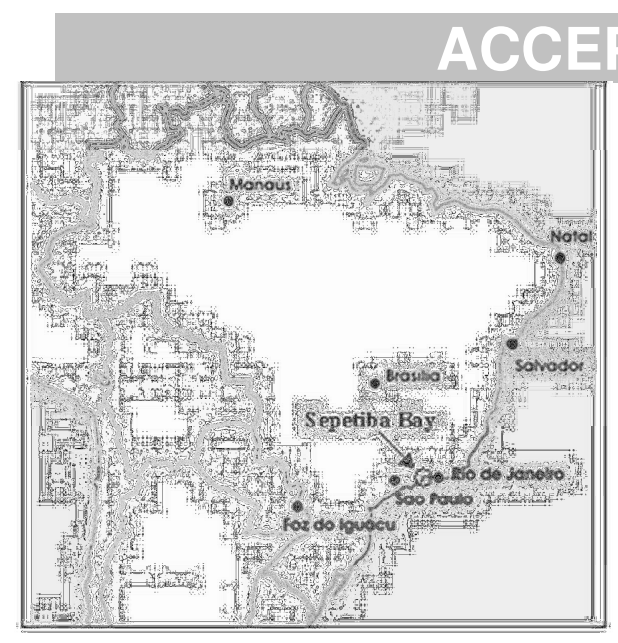




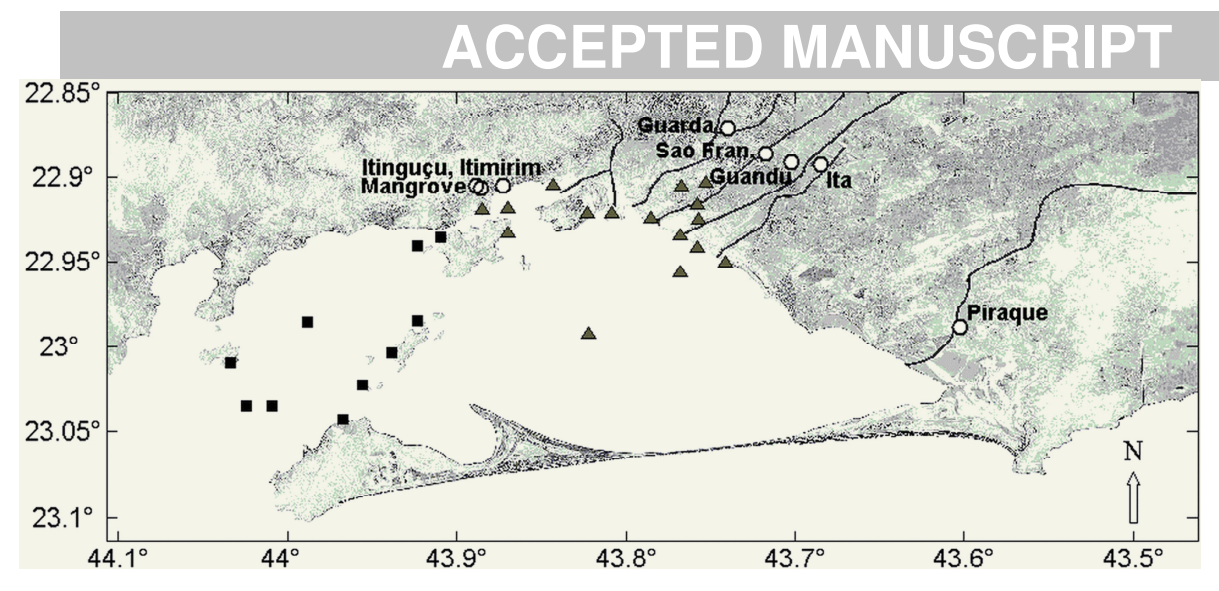


ACCEPTED MANUSCRIPT
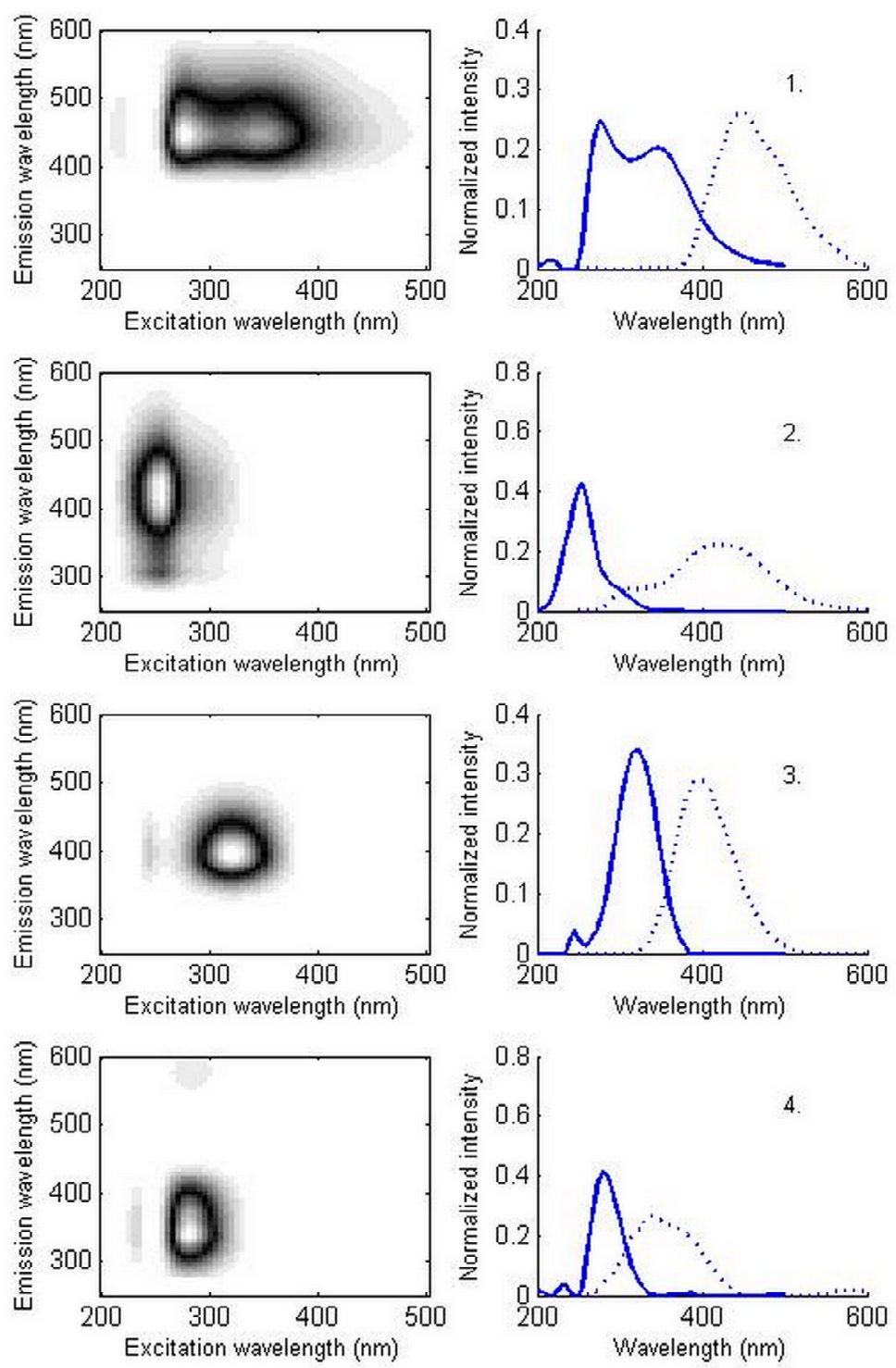

1 


\section{ACCEPTED MANUSCRIPT}

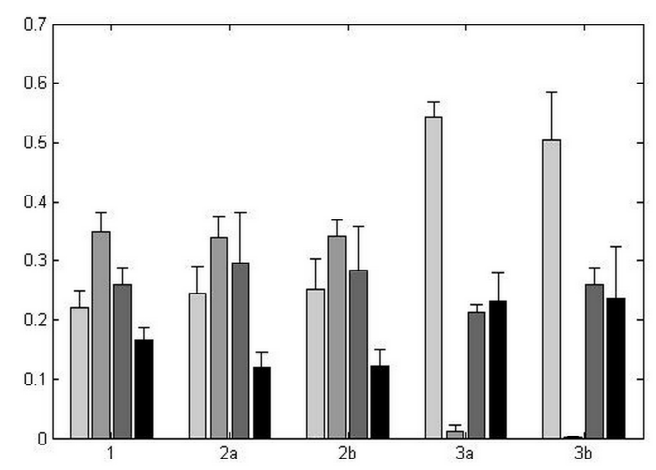




\section{ACCEPTED MANUSCRIPT}
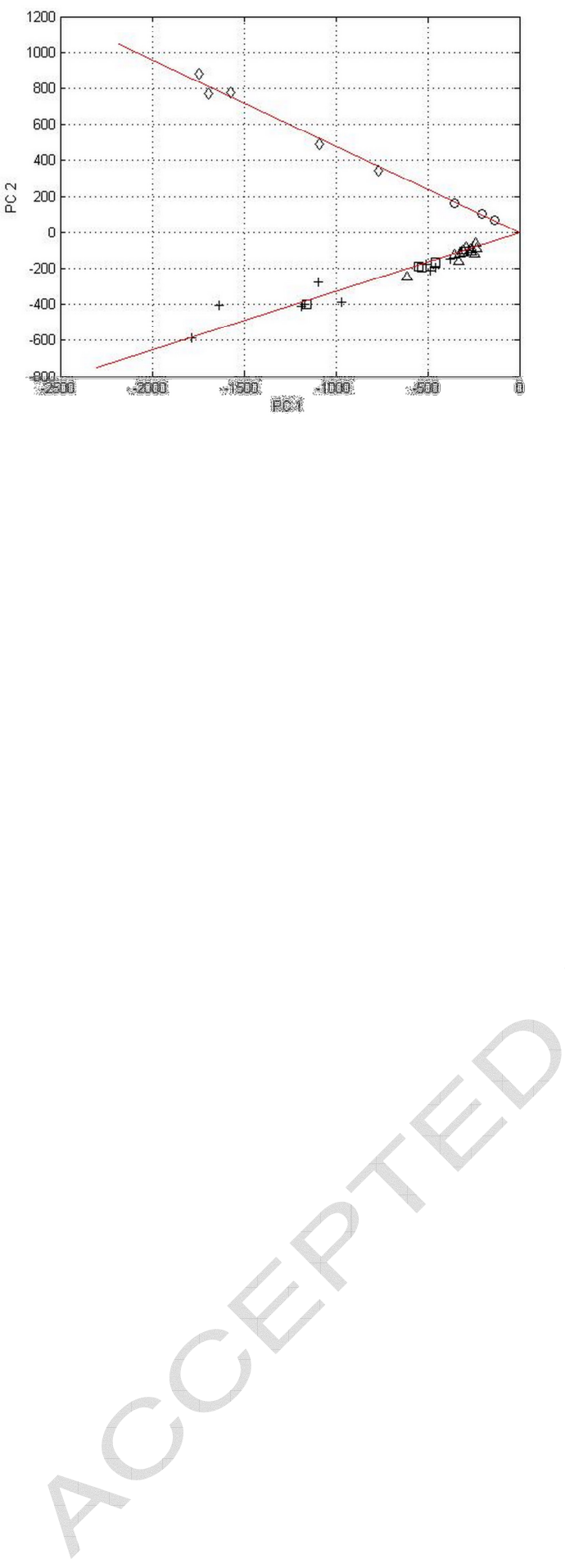